\title{
Control of KIT signalling in male germ cells: what can we learn from other systems?
}

\author{
Sridurga Mithraprabhu ${ }^{1}$ and Kate L Loveland ${ }^{1,2}$ \\ ${ }^{1}$ Monash Institute for Medical Research, Monash University, Clayton, Victoria 3168, Australia and ${ }^{2}$ Australian \\ Research Council Centre of Excellence in Biotechnology and Development, Callaghan, NSW 2308, Australia
}

Correspondence should be addressed to $K L$ Loveland who is now at Department of Biochemistry and Molecular Biology and Department of Anatomy and Developmental Biology, Monash University, Building 77, Level 1, Wellington Road, Clayton, Victoria 3800, Australia; Email: kate.loveland@med.monash.edu.au

\begin{abstract}
The KIT ligand (KITL)/KIT-signalling system is among several pathways known to be essential for fertility. In the postnatal testis, the KIT/KITL interaction is crucial for spermatogonial proliferation, differentiation, survival and subsequent entry into meiosis. Hence, identification of endogenous factors that regulate $K I T$ synthesis is important for understanding the triggers driving germ cell maturation. Although limited information is available regarding local factors in the testicular microenvironment that modulate KIT synthesis at the onset of spermatogenesis, knowledge from other systems could be used as a basis for identifying how KIT function is regulated in germ cells. This review describes the known regulators of KIT, including transcription factors implicated in KIT promoter regulation. In addition, specific downstream outcomes in biological processes that KIT orchestrates are addressed. These are discussed in relationship to current knowledge of mammalian germ cell development.

Reproduction (2009) 138 743-757
\end{abstract}

\section{Significance of research on the KIT/KITL-signalling pathway}

KIT receptor expression and interaction with KIT ligand (KITL) are crucial for proliferation, migration, survival and maturation of germ cells in embryonic and postnatal gonads (Yoshinaga et al. 1991, Dym et al. 1995, Packer et al. 1995, Orth et al. 1997, Vincent et al. 1998, de Rooij et al. 1999, Ohta et al. 2000, Yan et al. 2000a, Guerif et al. 2002, Prabhu et al. 2006, Runyan et al. 2006, Gu et al. 2009). In addition to serving essential functions in gametogenesis, KIT/KITL signalling is required for the development and function of haematopoietic cells, melanocytes, mast cells and interstitial cells of cajal, among other cell types. This information has been gained from studies of mice with mutations in the white spotting $(W)$ locus (encoding KIT) and the Steel $(S /)$ locus (encoding KITL). Some homozygous Kit mutations are embryonic lethal, while other homozygous and heterozygous mutations have differential effects on fertility, anaemia and pigmentation (Besmer et al. 1993). In the pre-cancerous human testis, $\mathrm{KIT}$ is a marker of carcinoma in situ cell (CIS), the preinvasive precursor gonocyte (Rajpert-De Meyts \& Skakkebaek 1994) that eventually develops into germ cell tumours. Genetic modifications in the locus encoding KITL in humans have recently been linked with testicular cancer risk in two screens of two independent population cohorts (Kanetsky et al. 2009, Rapley et al. 2009), firmly implicating KIT signalling as a key contributor to the development of germ cell tumours. Gain-of-function mutations in KIT contribute to specific human cancers, including small lung cell carcinoma, gastrointestinal stromal tumour (GIST) and prostate cancers (Kitamura \& Hirotab 2004, Sattler \& Salgia 2004). Therefore, identification of endogenous factors that modulate KIT synthesis is important for understanding disease development. Such knowledge can in turn be applied to understand the fundamental biology of germ cell maturation. This review focuses on recent developments in knowledge that applies to regulation of KIT and addresses its potential to enhance our understanding of germ cell maturation.

\section{Structures of KIT and KITL}

\section{KIT}

The Kit gene is allelic to the $W$ locus on mouse chromosome 5 (Chabot et al. 1988). The 21-exon gene encodes a $5.5 \mathrm{~kb}$ transcript that is translated into a product of $\sim 145 \mathrm{kDa}$ (Yarden et al. 1987). KIT belongs to a family of growth factor receptors with intrinsic tyrosine kinase activity that transduces growth regulatory signals across the plasma membrane. The KIT receptor has three main functional regions: the outer extracellular 
domain, a transmembrane region and intracellular domain (Fig. 1). The outer domain consists of five immunoglobin-like repeats required for ligand binding and dimerization (Blechman et al. 1995). The transmembrane region is a 23 amino acid hydrophobic domain, which anchors the receptor to the cell membrane. The 433 amino acid intracellular domain consists of three domains, with a proximal kinase region for ATP binding, a 70-100 amino acid non-conserved insert and a distal phosphotransferase kinase region (Blechman et al. 1993). Tyrosine (Tyr) residues in the



Figure 1 Schematic illustration of KIT receptor protein domain structures. The KIT extracellular domain has five immunoglobin-like repeats (green) required for ligand binding. The transmembrane domain (dark blue) anchors the receptor to the cell membrane. The intracellular domain (light blue) consists of a proximal kinase region for ATP binding, a non-conserved kinase insert (yellow) and a distal phosphotransferase kinase region. Isoforms of KIT are created by differences in the extracellular juxtamembrane domain of KIT (GNNK + and GNNK - ). Soluble KIT is proteolytically cleaved near the junction of the extracellular and transmembrane regions and binds KITL with affinity comparable with that of membrane-bound KIT. TR-KIT is comprised of the catalytic kinase domain and part of the nonconserved insert from the C-terminal of the mature full-length KIT, but lacks the entire extracellular domain (Albanesi et al. 1996). intracellular juxtamembrane domain serve as docking sites for signal transduction molecules that undergo activation (Roskoski 2005).

Two KIT receptor isoforms arise from alternative splicing in the extracellular juxtamembrane region (Fig. 1) distinguished by the presence or absence of a four amino acid region consisting of GNNK (Hayashi et al. 1991, Reith et al. 1991). Both isoforms bind with equal affinity to KITL (Caruana et al. 1999); however, KITL induces faster activation of the GNNK - form, while the GNNK + remains active for longer in myeloma cells (Montero et al. 2008). This is in accord with the more rapid SRC signalling kinetics of the GNNK - compared with the GNNK+ isoform (Voytyuk et al. 2003).

Truncated forms of the KIT protein originate from 2.3 and $3.2 \mathrm{~kb}$ transcripts synthesized uniquely in spermatids (Sorrentino et al. 1991). The $3.2 \mathrm{~kb}$ transcript, TR-KIT, encodes part of the non-conserved insert from the C-terminal tail region and the distal phosphotransferase kinase region, and it lacks the entire extracellular and transmembrane domain (Albanesi et al. 1996). TR-KIT cannot interact with KITL, so spermatids are independent of KITL stimulation. This KIT isoform is also found in the residual sperm cytoplasm and there is evidence for it serving a function in mouse oocyte activation at fertilization (Sette et al. 1997). A soluble KIT receptor (S-KIT) isoform has also been identified, which is proteolytically cleaved from the surface of haematopoietic cells, mast cells and endothelial cells and also circulates in human plasma (Wypych et al. 1995, Tajima et al. 1998, Ishiga et al. 2000, Nakamura et al. 2004). The cleavage truncates S-KIT at the junction of the transmembrane and extracellular domains, and this isoform binds KITL with affinity comparable with the membrane-anchored protein. It blocks KITL stimulation of haematopoietic colony growth in vitro, and thus one function of S-KIT is to modulate KITL bioactivity (Dahlen et al. 2001).

\section{KIT ligand}

The ligand for KIT, KITL, also known as stem cell factor and mast cell growth factor, is encoded on chromosome 10 in mice. The gene consists of nine exons and is syntenic with the SI locus (Zsebo et al. 1990a, $1990 b)$. This $30 \mathrm{kDa}$ glycoprotein is a member of the short-chain subgroup of helical cytokines, which includes macrophage colony-stimulating factor (CSF1), FLT3 ligand and platelet-derived growth factor (Zhang et al. 2000). The protein has four functionally important regions: a signal sequence, an extracellular domain, a transmembrane domain and a cytoplasmic domain (Fig. 2; Martin et al. 1990, Zsebo et al. 1990a, 1990b, Okada \& Suda 1992). The 25 amino acid N-terminal signal sequence is removed during intracellular trafficking and is similar to that of many other proteins targeted for the cell surface. The extracellular domain contains 


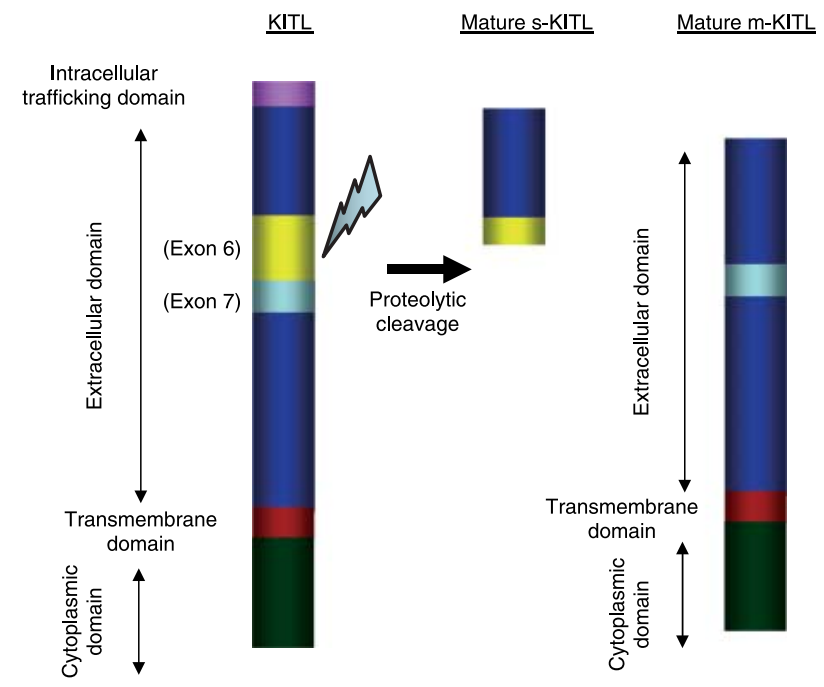

Figure 2 Schematic representation of the production of the two KITL isoforms. The Kitl mRNA encodes an intracellular trafficking domain (purple), which is cleaved when protein is targeted to the cell surface. The mature protein consists of an extracellular domain (blue), hydrophobic transmembrane domain (red) and cytoplasmic domain (green). Exon 6 (yellow) of Kitl encodes a site at which proteolytic cleavage occurs to generate a truncated soluble KITL (s-KITL). Cleavage also occurs with lower efficiency at a site encoded within exon 7 (pale blue) to generate a second s-KITL isoform. The membrane-bound KITL (m-KITL) lacks the primary cleavage site (exon 6) and remains as a membrane-bound protein (adapted from Loveland \& Schlatt (1997)).

the major structural elements of $\mathrm{KITL}$, including sequences that bind to KIT with high specificity. A hydrophobic domain of 26 amino acids functions as the transmembrane domain. When KITL binds to the KIT extracellular domain, it induces receptor dimerization and thus mediates autophosphorylation by the now adjacent tyrosine kinase domains. This generates a signal transduction cascade to the cell interior that ultimately leads to altered gene transcription (Lev et al. 1992), as discussed later in this review.
Alternative splicing at exon 6 of murine Kitl yields two distinct isoforms encoding membrane-bound (m-KITL) and soluble (s-KITL) proteins (Miyazawa et al. 1995). A 248 amino acid transmembrane precursor is processed at the primary cleavage site within the $84 \mathrm{bp}$ exon 6 to produce a soluble 165 amino acid isoform (s-KITL; Flanagan et al. 1991, Huang et al. 1992). This was initially demonstrated by the transfection of stromal cells with human cDNA that contained or lacked exon 6 (Toksoz et al. 1992). The alternate isoform, m-KITL, lacks the primary cleavage site and encodes a predominantly membrane bound form of 220 amino acids. An alternate form of the s-KITL protein can also be produced following cleavage at a site on exon 7; however, the rate of cleavage is much lower than that incurred within exon 6 sequences (Huang et al. 1992).

\section{Expression and function of $K I T$ during gametogenesis}

In the mouse, Kit mRNA is detected in primordial germ cells (PGCs) at embryonic day 7.5-8.0 (E7.5-8.0) and during their subsequent migration to the genital ridge (Fig. 3). This expression persists through their period of proliferation (Orr-Urtreger et al. 1990, Manova \& Bachvarova 1991), while somatic cells along the migratory pathway and genital ridges synthesize Kitl (Matsui et al. 1990, De Felici et al. 1996, Runyan et al. 2006, Gu et al. 2009). Presentation of KITL to PGCs is required for their adhesion to somatic cells, proliferation, migration and survival prior to E9.0 after which downregulation of KITL is associated with switching on the intrinsic apoptotic pathway in ectopic germ cells (Dolci et al. 1991, Godin et al. 1991, Runyan et al. 2006). In the absence of somatic cells, PGC migrates in response to a gradient of KITL (Farini et al. 2007). From E15 to day 3 in the mouse, KIT protein expression is markedly reduced, concordant with a period of germ cell quiescence (Prabhu et al. 2006).

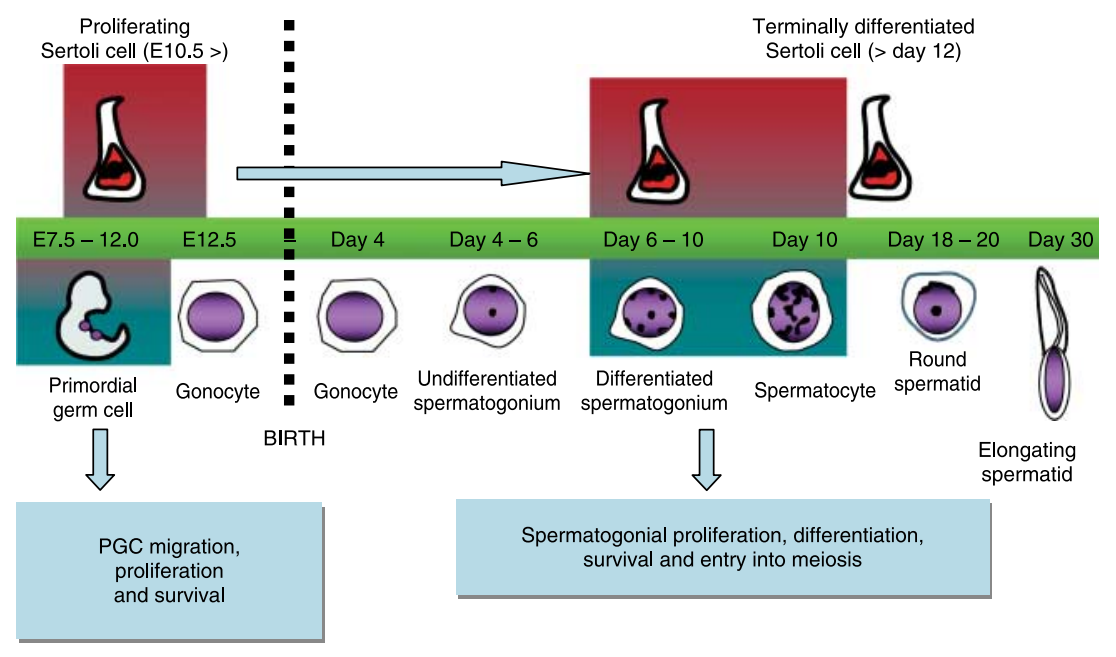

www.reproduction-online.org
Figure 3 KIT expression and function during gametogenesis. The timing of first appearance for different types of germ cells and Sertoli cell maturation status during testicular development are illustrated. Dark blue boxes represent specific germ cell stages when KIT is expressed. Dark green boxes illustrate the expression of KITL in Sertoli cells. The interactions of KIT and KITL yield distinct cellular outcomes depending on the stage of germ cell development (represented in light blue rectangles). Purple, germ cell nucleus; red, Sertoli cell nucleus. The timing of germ cell and Sertoli cell development is adapted from McCarrey (1993). 
In the postnatal rodent testis, between days 0 and 5, during the period of gonocyte migration from the centre to the periphery of the seminiferous cord, Kit mRNA is not readily detected in the mouse testis (Hasthorpe et al. 1999, Prabhu et al. 2006). Synthesis of Kit mRNA and protein during testicular development is concordant with the first appearance of differentiating spermatogonia, which occurs at approximately day 7 ; Kit mRNA persists at relatively lower levels in meiotic pachytene spermatocytes (Prabhu et al. 2006). It is intriguing that Kit mRNA can be detected in undifferentiated spermatogonia, while KIT protein expression is associated only with differentiating spermatogonia (Prabhu et al. 2006), as this suggests separate mechanisms exist to regulate Kit transcription and translation during spermatogenesis. The presence of KIT protein in spermatogonia has been routinely used as a marker to identify differentiating spermatogonia (Shinohara et al. 1999, 2000). KIT is also present in Leydig cells of the postnatal and adult testis and is implicated in their steroidogenic capacity and survival (Yan et al. 2000b, Rothschild et al. 2003, Prabhu et al. 2006). KITL protein is present in Sertoli cells starting from ages day 6 to 8 in the mouse testis (Rossi et al. 1991, Tajima et al. 1991a, 1991b). Culture of germ cells and immature Sertoli cells from day 2 and day 5 mice with the ACK2 antibody to block the interaction of the KIT receptor with KITL caused dosedependent inhibition of spermatogonial proliferation only in the day 5 mice, indicating that spermatogonial proliferation is directly associated with the onset of KIT receptor expression and its subsequent interaction with KITL (Tajima et al. 1994). The KIT and KITL interaction is required for maintenance and proliferation of differentiated KIT-positive spermatogonia (Fig. 3), but not for the preceding initial step of spermatogonial cell differentiation (Ohta et al. 2000, 2003). KIT signalling is also critical for progression to and survival during the meiotic pachytene stage of spermatogenesis (Packer et al. 1995, Vincent et al. 1998, Yan et al. 2000a). Transcriptome analysis of spermatogonia from day 7 mouse testes stimulated with s-KITL for $24 \mathrm{~h}$ indicated that KITL modifies the expression of genes known to be up-regulated or down-regulated in spermatogonia during the transition from the mitotic to the meiotic cell cycle. This is consistent with a role for KIT activation by KITL in male germ cell entry into meiosis (Rossi et al. 2008).

\section{Regulators of KIT mRNA synthesis}

\section{Growth factors}

The biological significance of KIT expression at the onset of spermatogenesis relates to its essential role in spermatogonial differentiation (de Rooij et al. 1999). Hence, the timing of mRNA up-regulation is consistent with the current understanding that KIT is a marker of differentiating spermatogonia. However, limited data are available regarding the endogenous factors that modulate KIT at this crucial time point. A summary of the growth factors that are known to regulate KIT in the testis and other systems is provided in Table 1 and are discussed below.

\section{Transforming growth factor $\beta$ superfamily}

Ligands of the transforming growth factor $\beta$ (TGFB) superfamily of growth factors regulate many cellular functions including cell growth, adhesion, migration, differentiation and apoptosis. Their actions are essential for embryonic development, in particular for germ layer specification and patterning during embryogenesis (Chan \& Etkin 2001). The mammalian TGFB superfamily contains $\sim 40$ known ligand subunits, each forming a dimer to affect signal transduction via a serine/threonine kinase receptor in target cells (Loveland et al. 2007, Schmierer \& Hill 2007). This includes 3 TGFB isoforms, 4 activin $\beta$ subunits, nodal, 10 bone morphogenetic proteins (BMPs) and 11 growth differentiation factors (Schmierer \& Hill 2007). Of particular relevance to male reproductive physiology are the inhibins, activins and BMPs (Itman et al. 2006).

The only TGFB superfamily member known to control Kit mRNA and protein synthesis in the testis to date is BMP4. In one study, northern-blot analysis of Bmp4 expression indicated that this factor is produced exclusively in Sertoli cells from day 4 testis and is subsequently down-regulated in older pre-pubertal Sertoli cells (Pellegrini et al. 2003). In other reports, the, Bmp4 mRNA was detected in germ cells in day 7 and older ages (Hu et al. 2004, Baleato et al. 2005). Its type I receptor, BMPR1A, and one of its downstream transcription factors, SMAD5, are present both in proliferating PGCs and in postnatal spermatogonia (Pellegrini et al. 2003). Germ cell-enriched cultures from day 4 mouse testes exhibit increased KIT levels and display a mitogenic response to KITL following BMP4 treatment. Thus, the commitment of spermatogonia to differentiate may require the expression of BMP4 during the first spermatogenic wave (Pellegrini et al. 2003); however, this has not been tested in vivo. In a similar manner, BMP4 stimulation of Kit mRNA levels was also observed in the immature neural crest cell line, NCCmelb4m5, in which BMP4 was suggested to programme melanoblasts to enter a KIT-dependent phase of melanogenesis, required for their progressive maturation (Ito et al. 2004, Kawakami et al. 2008).

Other members of this superfamily, TGFB1 and activin $\mathrm{A}$, are known to modulate $K I T$ in systems other than the testis. Treatment with TGFB1 elevates KIT mRNA levels in T-leukaemia cells and in melanoblasts (Tomeczkowski et al. 1998, Kawakami et al. 2002). In contrast to these two studies that reported a stimulatory impact, the capacity of TGFB1 to reduce KIT levels 
Table 1 Summary of regulators of KIT synthesis. Modulation of KIT by growth factors, hormones, cytokines and vitamins is indicated.

\begin{tabular}{|c|c|c|c|c|}
\hline Type & Factor & Outcome & Cell type & References \\
\hline \multirow{10}{*}{$\begin{array}{l}\text { Growth } \\
\text { factors/hormones }\end{array}$} & \multirow[t]{2}{*}{ BMP4 } & \multirow[t]{2}{*}{$\uparrow$} & Undifferentiated spermatogonia culture & Pellegrini et al. (2003) \\
\hline & & & Immature melanocytes cell line NCCmelb4M5 & Kawakami et al. (2008) \\
\hline & Activin A & $\downarrow$ & Murine erythroleukaemia cell line & Hino et al. (1995) \\
\hline & \multirow[t]{2}{*}{ TGFB1 } & \multirow[t]{2}{*}{$\uparrow$} & T-leukaemia cell lines & Tomeczkowski et al. (1998) \\
\hline & & & Melanoblast cell line & Kawakami et al. (2002) \\
\hline & \multirow[t]{4}{*}{ TGFB1 } & \multirow[t]{4}{*}{$\downarrow$} & $\begin{array}{l}\text { Mouse peritoneal mast cells and } \\
\text { cultured human mast cells }\end{array}$ & Norozian et al. (2006) \\
\hline & & & $\begin{array}{l}\text { Human colorectal carcinoma } \\
\text { cell line HT-29 CRC }\end{array}$ & Bellone et al. (1997) \\
\hline & & & $\begin{array}{l}\text { Human acute myeloid leukaemia } \\
\text { (AML) blast cells }\end{array}$ & $\begin{array}{l}\text { Heinrich et al. (1995) and } \\
\text { Hassan \& Zander (1996) }\end{array}$ \\
\hline & & & $\begin{array}{l}\text { Human CD } 34+\text { progenitor } \\
\text { cell population }\end{array}$ & $\begin{array}{l}\text { Heinrich et al. (1995) and } \\
\text { Sansilvestri et al. (1995) }\end{array}$ \\
\hline & FGF2 & $\uparrow$ & Murine erythroleukaemia cell line & Burger et al. (2002) \\
\hline \multirow[t]{6}{*}{ Cytokines } & IL1A & $\downarrow$ & $\begin{array}{l}\text { Inflammatory model of human umbilical } \\
\text { vein endothelial cells }\end{array}$ & Konig et al. (1997) \\
\hline & IL1A & $\uparrow$ & Bone marrow cells of irradiated mice & Neta et al. (1994) \\
\hline & \multirow[t]{3}{*}{ TNFA } & \multirow[t]{3}{*}{$\downarrow$} & Human vascular endothelial cells & Buzby et al. (1994) \\
\hline & & & Haematopoietic cell line & Jacobsen et al. (1995) \\
\hline & & & $\begin{array}{l}\text { Normal and acute myeloid leukaemic } \\
\text { cells of human }\end{array}$ & Khoury et al. (1994) \\
\hline & TNFA & $\uparrow$ & Human acute myeloid leukaemic cells & Hassan \& Zander (1996) \\
\hline \multirow[t]{6}{*}{ Cytokines } & \multirow[t]{3}{*}{ IL4 } & \multirow[t]{3}{*}{$\downarrow$} & Human acute myeloid leukaemic cells & Hassan \& Zander (1996) \\
\hline & & & Human mast cell line HMC-1 & Sillaber et al. (1991) \\
\hline & & & Human colorectal cancel cell line & Lahm et al. (1995) \\
\hline & IL1B & $\downarrow$ & Human vascular endothelial cells & Buzby et al. (1994) \\
\hline & IL10 & $\downarrow$ & Human mast cell line HMC-1 & Mirmonsef et al. (1999) \\
\hline & CSF2 & $\downarrow$ & Human mast cells & Welker et al. (2001) \\
\hline \multirow[t]{2}{*}{ Vitamins } & \multirow[t]{2}{*}{$\begin{array}{r}\text { Retinoic acid } \\
(\text { vitamin } A)\end{array}$} & \multirow[t]{2}{*}{$\uparrow$} & $\begin{array}{l}\text { Spermatogonia in vitamin } \\
\text { A-deficient mice }\end{array}$ & Schrans-Stassen et al. (1999) \\
\hline & & & Gonocytes & $\begin{array}{l}\text { Wang \& Culty (2007) and } \\
\text { Zhou et al. (2007) }\end{array}$ \\
\hline
\end{tabular}

$\uparrow$, up-regulation of KIT; $\downarrow$, down-regulation of KIT. References for each factor implicated in KIT regulation are provided.

has been demonstrated in several systems (Heinrich et al. 1995, Sansilvestri et al. 1995, Hassan \& Zander 1996, Bellone et al. 1997, Norozian et al. 2006). This repressive effect of TGFB1 on KIT may occur through accelerated degradation of KIT mRNA, rather than through a direct impact on mRNA synthesis (Dubois et al. 1994, Heinrich et al. 1995). Activin A represses Kit mRNA and protein synthesis over 48-72 $\mathrm{h}$ in a murine erythroleukaemia cell line (Hino et al. 1995). This erythroblast cell line has relatively high levels of KIT; with addition of activin, these cells undergo differentiation to form erythroid cells.

\section{Retinoic acid}

Vitamin A, or dietary retinol, is required for normal spermatogenesis, and its function has been extensively studied using in vivo models and culture systems. Adult vitamin A-deficient mice (VAD; deprived of dietary vitamin A) exhibit seminiferous tubules containing only Sertoli cells, type A spermatogonia and few preleptotene spermatocytes. These type A spermatogonia are almost all arrested before differentiation into $A_{1}$ spermatogonia, and Kit mRNA and protein levels are significantly reduced in VAD testis. Administration of vitamin $A$ to these animals results in synchronized spermatogenesis emerging from type A spermatogonia and enhanced expression of Kit (Schrans-Stassen et al. 1999). More recently, gonocyte culture studies have established that retinoic acid (RA) stimulated Kit levels by acting directly on germ cells (Wang \& Culty 2007, Zhou et al. 2007). Besides increasing Kit expression, RA also up-regulated Kitl levels in Sertoli cells, resulting in increased levels of the early meiotic cell markers stimulated by RA gene 8 (STRA8) and DMC1. This activation is independent of germ cell viability and occurs through the phosphatidylinositol 3-kinases (PI3K) and MAP kinase (MAPK) pathways (Pellegrini et al. 2008). Thus, RA may control the timing of meiosis by influencing both somatic and germ cell compartments of the postnatal testis at least partially through activation of the KITL/KIT system.

\section{Hormones and cytokines}

KIT expression is modulated by various proinflammatory signals. Differential effects are induced by some cytokines depending on the model or type of cell system used for investigation. Among these, interleukin $1 \alpha(I L 1 A)$, lipopolysaccharides, tumour necrosis factor a (TNFA), IL4, IL1B, granulocytemacrophage CSF2, IL10 and basic fibroblast growth 
factor 2 have been reported to modulate KIT synthesis (Sillaber et al. 1991, Buzby et al. 1994, Khoury et al. 1994, Neta et al. 1994, Jacobsen et al. 1995, Lahm et al. 1995, Hassan \& Zander 1996, Konig et al. 1997, Mirmonsef et al. 1999, Welker et al. 2001, Burger et al. 2002). A summary of these published reports listing the cell type tested is provided in Table 1.

\section{KIT promoter region}

The expression pattern of KIT is dynamic and thus highly regulated during development; however, the molecular basis for KIT transcriptional regulation remains largely unknown. KIT promoter analyses have been performed for mouse and human genes; in general, these studies indicate that interacting mechanisms may coordinately regulate KIT expression.

The transcription initiation site of the KIT promoter is located at $58 \mathrm{bp}$ upstream of the initiation codon in both mice and humans. Analysis of the sequence upstream of the transcription initiation site reveals a TATA-less and a non-GC-rich promoter region. The 2.7-5.0 kb upstream sequences appear to be required for transcription inhibition (Yamamoto et al. 1993, Chu \& Besmer 1995, Vandenbark et al. 1996). Investigation of six DNase Ihypersensitive sites within the promoter and first intron of the mouse Kit gene in haematopoietic cells, in PGCs (Cairns et al. 2003) and in mast cells (Berrozpe et al. 2006) revealed that DNase I-hypersensitive site 2 acts as an enhancer, integrating transcriptional signals in PGCs and haematopoietic cells. Potential binding sites for transcription factors pertinent to KIT expression, such as specificity protein 1 (SP1), stem cell leukaemia (SCL), putative binding sites for activator protein 2 (AP-2), GATA1, MYB, ETS and POU domains, have been identified (Yamamoto et al. 1993, Yasuda et al. 1993, Chu \& Besmer 1995).

\section{Upstream transcription factors}

The upstream transcription factors that enhance or repress promoter region activity ultimately determine the cellular expression profile of KIT, and thus influence the cellular functions that KIT signalling facilitates. Regulation of KIT promoter activity is tissue specific and complex. Studies of these factors during normal testicular development and testicular pathologies will provide valuable clues about the mechanisms underlying development and maintenance of germ cell tumours in which surface KIT is consistently present.

\section{Testicular transcription factors}

Promyelocytic leukaemia zinc finger (PLZF)

The only transcription factor known in the testis to directly bind to Kit and affect its transcription during spermatogonial differentiation is PLZF, renamed as
ZBTB16. Male mice lacking Zbtb16 exhibit progressive germ cell depletion due to exhaustion of the spermatogonial stem cell pool (Costoya et al. 2004). ZBTB16 directly represses transcription both of endogenous Kit and of a reporter gene controlled by the Kit promoter. A significant increase in Kit levels is also observed in spermatogonia isolated from Zbtb16 null mice (Filipponi et al. 2007). ZBTB16 has also been suggested to affect the expression of $K I T$ and aid haematopoietic stem cell mobilization from the bone marrow to the peripheral blood (Quaranta et al. 2006). ZBTB16-mediated negative control of Kit was demonstrated in normal haematopoietic progenitor cells and in acute myeloid leukaemias (Spinello et al. 2009).

\section{AP-2G}

The KIT promoter region has three putative AP-2-binding sites (Chu \& Besmer 1995) within the $1.2 \mathrm{~kb}$ region upstream of the promoter (Yamamoto et al. 1993). AP-2 protein binds directly to the KIT promoter in melanoma cell lines, when tested using a luciferase reporter gene (Huang et al. 1998). Human foetal gonocytes coexpress $\mathrm{KIT}$ and $\mathrm{AP}-2 \mathrm{G}$, suggesting that they play linked roles in maintaining the proliferative state of foetal germ cells (Pauls et al. 2005). With relevance to the development of germ cell tumours, KIT is a marker of intratubular germ cell neoplasia that is coexpressed with AP-2G (Hong et al. 2005). However, to date there has been no examination of whether AP-2G directly promotes KIT transcription in germ cells of the normal postnatal and adult testis.

\section{SOHLH1 and SOHLH2}

Spermatogenesis and oogenesis specific basic helixloop-helix 1 and 2 are transcription factors essential for early spermatogenesis (Ballow et al. 2006). Both SOHLH1 and SOHLH2 proteins are present in the differentiating spermatogonia subtypes (Ballow et al. 2006, Toyoda et al. 2009). Since mice lacking either SOHLH1 or SOHLH2 show disturbed spermatogonial differentiation resulting in testicular phenotypes similar to Kit-mutant mice, it was suggested that both these proteins promote the differentiation of KIT-positive cells in testes (Ballow et al. 2006, Toyoda et al. 2009). This possibility remains to be formally tested.

\section{SIX5}

SIX5 belongs to the SIX family of transcription factors containing the SIX domain and the SIX homeodomain required for specific DNA binding (Kawakami et al. 2000). Loss of SIX5 results in male infertility and a reduction in testicular mass, as both survival and maturation of germ cells are affected. In addition, Leydig cells exhibit hyperproliferation, and increased $\mathrm{FSH}$ levels are detected in postnatal $\operatorname{Six} 5^{-/-}$mice. 
KIT protein levels are decreased in Six $5^{-1-}$ mice relative to wild-type mice leading to the suggestion that this reduction in KIT could underlie the disturbed spermatogenic viability and enhanced Leydig cell proliferation (Sarkar et al. 2004), although no direct link between SIX5 and KIT gene has been established.

\section{Non-testicular transcription factors}

\section{Specificity protein-1}

The KIT promoter region contains several potential SP1-binding sites within the highly GC-rich region between 83 and $124 \mathrm{bp}$ upstream of the $5^{\prime}$ transcription initiation site in mice and humans. SP1 selectively binds to a single site within this region, and site-directed mutagenesis of the -93 or -84 promoter region reduces promoter-reporter activity to basal levels in KIT-expressing cells. These results indicate that SP1 binding is a selective process that is essential for core promoter activity, despite the presence of multiple additional SP1-binding sites in the KIT promoter (Park et al. 1998). Silencing of SP1 during erythroid differentiation resulted in elevated Kit expression, indicating a repressive role for SP1 in Kit regulation in haematopoietic progenitor cells (Hu et al. 2007).

\section{Stem cell leukaemia}

SP1 forms a complex with the SCL protein to maintain pluripotency of haematopoietic stem cells (Lecuyer et al. 2002). SCL, also known as T-cell acute lymphocytic leukaemia-1 is a basic helix-loop-helix transcription factor, first shown to function upstream of $K I T$ in a haematopoietic cell line (Krosl et al. 1998). In normal haematopoietic cells, a motif containing overlapping $\mathrm{SCL}, \mathrm{SP} 1$ and E2A sites within the promoter region regulates KIT transcription (Lecuyer et al. 2002). Appropriate activation of the KIT promoter depends on the combined interaction of all complex members. Since $\mathrm{SCL}$ is down-regulated in maturing cells, it has been suggested that loss of SCL inactivates the SCL complex with the resulting down-regulation of KIT expression, an important event in pluripotent haematopoietic cell differentiation (Lecuyer et al. 2002).

\section{MYB and ETS}

Of the several MYB and ETS-binding domains identified in the KIT promoter region (Chu \& Besmer 1995), two MYB-binding motifs, MYB1, a partial repressor, and MYB2, a positive element, appear essential for the regulation of KIT expression (Vandenbark et al. 1996). A reporter construct containing the Kit promoter was activated when cotransfected with a MYB expression vector, providing further evidence of a role for Myb in the regulation of KIT (Hogg et al. 1997). Overexpression of the proto-oncogene c-MYB in avian neural crest cells increased KIT and subsequent KITLKIT signalling, transforming these cells into melanocytes and thereby establishing a role for c-MYB in KIT regulation (Karafiat et al. 2007). Similarly, c-MYB knockdown in normal erythroid progenitor cells demonstrated that c-MYB is required for KIT expression in erythroid cells (Vegiopoulos et al. 2006). It has also been shown that C-MYB and ETS2 coexpression augmented transactivation of KIT promoter constructs in contrast to cells transfected with either construct alone (Ratajczak et al. 1998). A role for the c-MYB in activation of germ cell KIT expression has not been investigated yet.

\section{GATA1}

Evidence that GATA1 represses Kit synthesis was demonstrated in a study employing a GATA1-null erythroblast cell line that proliferates in a KITLdependent fashion. Upon restoration of GATA1 function, these cells undergo $G_{1}$ cell cycle arrest concordant with decreased levels of Kit (Munugalavadla et al. 2005). In the testis, GATA1 is expressed in Sertoli cells and in Leydig tumour cells (Ito et al. 1993, Yomogida et al. 1994, Onodera et al. 1997, Feng et al. 1998). Therefore, whereas GATA1 may regulate Kit levels in Leydig cells, it most likely does not play a role in regulating Kit levels in spermatogonia. This observation highlights the need to define the cell-type-specific mechanisms that affect KIT levels.

\section{MicroRNAs}

MicroRNAs are small non-coding RNAs that act as posttranscriptional regulators of gene expression (He \& Hannon 2004). Kit has been described as a target of Mir221 and Mir222 during erythropoiesis, melanogenesis and in cancer progression (Felli et al. 2005, Felicetti et al. 2008). MicroRNAs are also prevalent during testicular germ cell tumour development (Looijenga et al. 2007), although the contribution of microRNAs that specifically affect KIT mRNA levels in the testis is yet to be determined.

\section{KITL/KIT-signalling pathways}

The first three immunoglobulin-like extracellular domains of KIT are required for ligand binding, while the fourth immunoglobin domain is required for receptor dimerization (Blechman et al. 1995). Bivalency of the KITL facilitates the dimerization of KIT that induces rapid intracellular Tyr autophosphorylation (Reith et al. 1991, Lev et al. 1992). The residues that initially undergo phosphorylation are within the intracellular juxtamembrane segment, and these include Tyr residues Tyr567 and Tyr569 in the murine protein. Other phosphorylation targets are Tyr701, Tyr719 and Tyr728, located in the kinase insert domain (Roskoski 2005). The resulting 
phosphotyrosine residues serve as docking sites for particular signal transduction molecules, which typically bind and phosphorylate a specific cytoplasmic protein during the initiation of the cellular signal transduction cascade (Fig. 4).

The activation and recruitment of different downstream-signalling pathways in response to the KIT/KITL interaction are critical for generating distinct developmental outcomes. Each orchestrates distinct cell functions, highlighting the need to study each of the different KIT-signalling pathways to understand how germ cell biology is modulated by KIT activity. In spermatogenesis, the KIT/KITL interaction is critical at the onset of spermatogenesis, while down-regulation of KIT signalling during spermiogenesis is also important. Evidence for the need to control KIT function was provided by generating mice with a mutation (D814V) that renders the KIT kinase constitutively active (Piao et al. 1996). Abnormalities emerge in spermiogenesis, with the transition from round into elongating spermatids interrupted (Schnabel et al. 2005). These observations demonstrate that KIT signalling must be reduced at later stages of germ cell development for normal sperm formation.

The KIT/KITL interaction is known to trigger five types of signalling pathways; the type of pathway selected appears to be unique to the cell type or developmental stage at which this interaction is invoked (Fig. 4). The key mediators of these pathways are $\mathrm{PI} 3 \mathrm{~K}, \mathrm{~V}$-src avian sarcoma (Schmidt-Ruppin A-2) viral oncogene homologue (SRC) kinases, JAK/STATs, RAS/MAPK and the
phospholipase-C $\gamma$ (PLCG; Sattler \& Salgia 2004, Reber et al. 2006). Each pathway contributes to critical cell functions that include migration, proliferation and survival, as discussed below. For some of these, we have little to no information about their importance at each phase of testis development and spermatogenesis when KIT is active.

\section{Phosphatidylinositol 3-kinase}

The best characterized pathway downstream of KIT/KITL signalling of these with regard to structure-function relationships involves the PI3K heterodimer, composed of an $85 \mathrm{kDa}$ regulatory subunit and a catalytic subunit of $110 \mathrm{kDa}$. Its potential substrates include phosphatidylinositol, phosphatidylinositol-4-phosphate and phosphatidylinositol-4, 5-bisphosphate (Duronio et al. 1998, Shepherd et al. 1998). Tyr719 of murine KIT (Y721 of human KIT) associates with the $85 \mathrm{kDa}$ subunit of PI3K. This pathway has functions that vary with the cell lineage in KITL-mediated responses, including adhesion (via c-JUN and c-FOS activation), proliferation (via AKT and $\mathrm{p} 70 \mathrm{~S} 6 \mathrm{~K}$ ) and survival (via AKT and BAD regulation; Serve et al. 1994; Fig. 4). Studies of the contribution of $\mathrm{PI} 3 \mathrm{~K}$ in KIT signalling employ a mutant form of KIT in which the Tyr at position 719, normally capable of recruiting PI3K when phosphorylated, is changed to a phenylalanine residue, termed Y719F.

KITL/KIT activation of the PI3K/AKT pathway appears to be crucial exclusively in postnatal stage spermatogenesis, since the only obvious phenotype in the Y719F

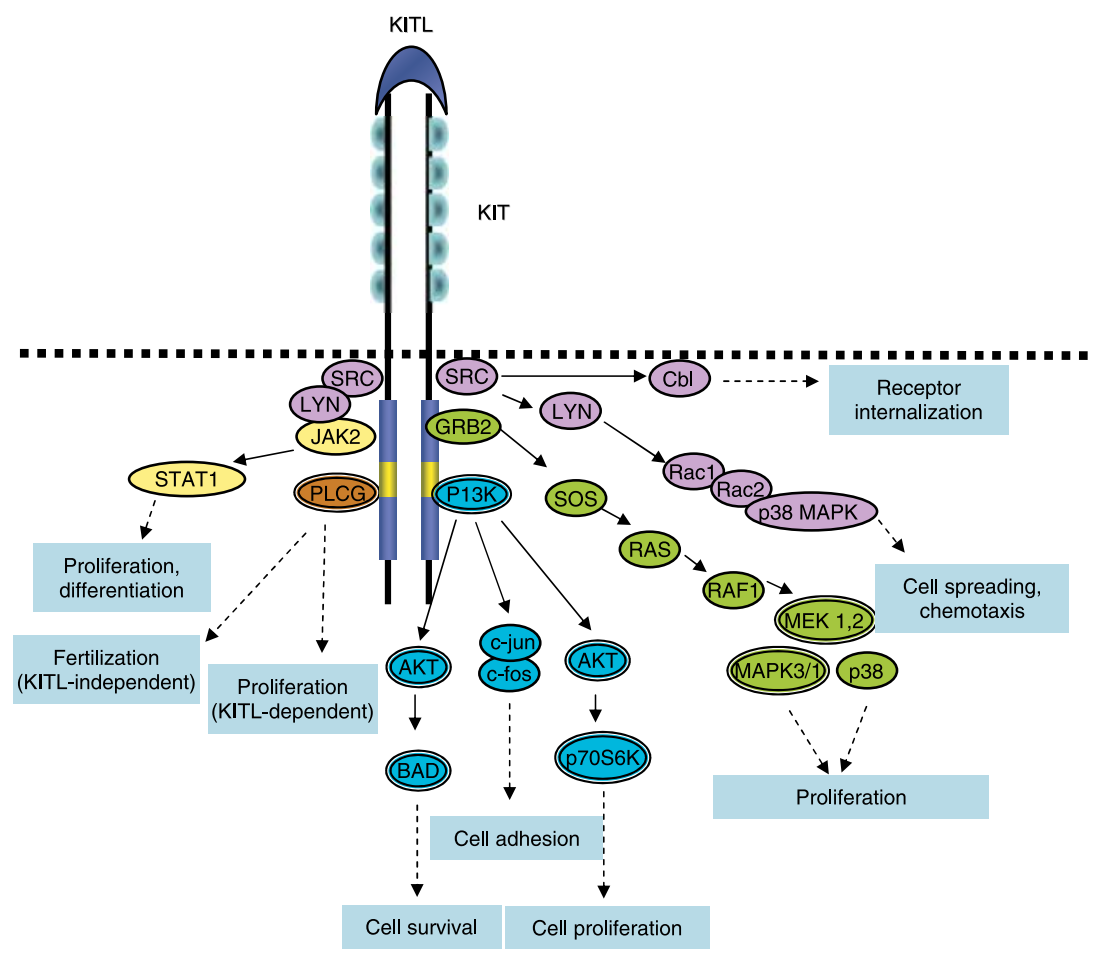

Figure 4 Signalling pathways and downstream cellular functions activated by KITL-mediated phosphorylation of KIT. Five pathways are known to be activated in response to KITL stimulation. The PI3K pathway results in cell survival, adhesion and proliferation (blue circles). The SRC kinase pathway is required for receptor internalization, chemotaxis and proliferation (purple circles). The MAP kinase pathway (green) mediates gene transcription and proliferation; JAK/STAT (yellow) signalling is essential for proliferation and differentiation. The PLCG pathway (orange) mediates KITL-independent sperm-egg fertilization and KITL-dependent proliferation in haematopoietic cells (adapted from Roskoski (2005) and Reber et al. (2006)). Double-line circles represent the pathways that are active during spermatogenesis. 
mutant is sterility in homozygous males, arising from reduced proliferation and subsequent extensive apoptosis in spermatogonia (Blume-Jensen et al. 2000). These mice exhibited no impact of the mutation in embryonic gametogenesis (Kissel et al. 2000). The signalling pathway involving the recruitment of PI3K and p70S6 kinase has also been demonstrated to promote cell cycle progression during the initiation of type A spermatogonial proliferation (Feng et al. 2000). KITL-induced PI3K recruitment also leads to AKT activation (a substrate in PI3K pathway) and to subsequent phosphorylation of the pro-apoptotic factor BAD. This phosphorylation inhibits BAD activity, thereby promoting cell survival (Blume-Jensen et al. 1998). PI3K is also active during foetal germ cell migration, activating SRC kinase/AKT autophosphorylation. LY294002, a specific inhibitor of PI3K, abolished KITL-dependent PGC migration and inhibited AKT phosphorylation in vitro (Farini et al. 2007).

\section{SRC kinase pathway}

KITL induces the activation of multiple SRC family members, including SRC, TEC, LYN and FYN (Blume-Jensen et al. 1994, Tang et al. 1994, Linnekin et al. 1997). These SRC proteins associate with phosphorylated murine Y567 (Y568 of human) and murine Y569 (Y670 of human) in the intracellular juxtamembrane domain of KIT (Roskoski 2005, Reber et al. 2006). SRC protein kinases are required for (a) normal internalization of the KIT receptor via phosphorylation of the CBL proteins (Shivakrupa \& Linnekin 2005) and (b) cell spreading and chemotaxis via the RAC1, RAC2 and MAPK p38 pathway (Samayawardhena et al. 2007). Mutations at Y567 and Y569 affect cell migration in IL3-dependent murine pro-B cell line (Ueda et al. 2002). In contrast to the PI3K function in the postnatal testis, mutation at Tyr 567 (Y567F), does not affect fertility of homozygous mutant males; instead, it affects only precursors of T-cell and B-cell development (Agosti et al. 2004). This demonstrates that KIT downstream-signalling pathways are specific for different cellular and developmental contexts in vivo. SRC kinase signalling also converges with other signalling pathways to affect cell-specific functions. SRC kinase signalling affects cell migration and is active during PGCs migration in vitro. The SRC kinase inhibitors, PP2 and SU6656, caused significant reduction in KITL-dependent PGC migration and AKT phosphorylation in mouse PGCs (Farini et al. 2007).

\section{JAK/STAT pathway}

Conventionally associated with cytokine signalling, Janus kinase family members play critical roles in haematopoietic lineages and in cell proliferation, as illustrated by animals deficient in JAK1, JAK2 and JAK3 (Linnekin 1999). The key signalling molecules that activated downstream of JAK proteins are STATs. KITL addition to the human megakaryoblastic cell line MO7e and to normal haematopoietic progenitor cells induces phosphorylation of JAK2 and subsequently activates STAT1 (Deberry et al. 1997). KITL also stimulates STAT3 activation in a human myeloid cell line (Gotoh et al. 1996) and STAT5 in bone marrowderived mast cells (Ryan et al. 1997). KITL-induced JAK/STAT activation is suggested to play a crucial role in foetal liver haematopoietic progenitor cell proliferation and differentiation (Linnekin et al. 1996). The JAK/STAT pathway is also activated in response to phosphorylation at Y567 (which also recruits SRC) and Y719 (recruits PI3K) for mast cell proliferation (Timokhina et al. 1998). In the Drosophila testis, in the absence of JAK/STAT signalling, germ line stem cells differentiate but fail to self-renew (Tulina \& Matunis 2001). There is yet no evidence of a role for JAK/STAT activation during KIT/KITL signalling in the mammalian testis.

\section{MAP kinases}

Phosphorylation at Y703 in the KIT intracellular region binds the growth factor receptor-bound protein-2 (GRB2; Thommes et al. 1999). In this position, GRB2 associates with the son-of-sevenless protein, and this complex interacts with and activates the small G-protein, RAS. Activated RAS regulates the MAPK cascade first through recruitment of RAF1 and then MEK1/2, p38 and MAPK3/1 (Reber et al. 2006). These MAPKs directly influence transcription factor activity and thereby regulate gene transcription. MAPK signalling is also activated in mouse PGCs in response to recombinant KITL treatment (Farini et al. 2007). KITL-induced murine spermatogonial cell cycle progression is also partly mediated by the MAPK pathway, through transient activation of MAPK3/1 (Dolci et al. 2001).

\section{Phospholipase- $\mathrm{C \gamma}$}

PLCG activation occurs in response to stimulation by m-KITL, but not s-KITL, through phosphorylation at KIT Y728 in myeloid cells (Gommerman et al. 2000). This demonstrates that there are different signalling outcomes mediated by distinct KITL isoforms. In addition, transfection of COS cells with the murine TR-KIT leads to activation of PLCG (Sette et al. 1998). TR-KIT-mediated PLCG activation is implicated in the resumption of meiosis in mouse eggs (Sette et al. 1998, 2002). Thus, this pathway is used in both KITL-dependent and KITL-independent signalling (Fig. 4). 


\section{Downstream factors and functions}

Identification of KIT signalling targets is required to understand the cell development fates that KIT and KITL orchestrate. This section describes some of the downstream target proteins of KIT signalling, which may provide insight for research directed towards clinical application and understanding human diseases. There is currently little information available to link KIT signalling with direct transcriptional targets during spermatogenesis, and this remains an important avenue for future studies in relationship to male fertility.

\section{SLUG (SNAI2)}

SLUG is a member of the Snail family of zinc finger transcription factors, evolutionarily conserved proteins found in vertebrates and invertebrates, which have been implicated in the generation and migration of mesoderm and neural crest cells in several vertebrate species (Nieto et al. 1994). Snai2-mutant mice, like Kit- or Kitldefective mice, have a complex phenotype including pigmentation, gonadal and haematopoietic defects (Perez-Losada et al. 2002). Testes from 6-week-old Snai2-deficient mice exhibit testicular atrophy and an overall reduction in seminiferous tubule size, which is also characteristic of $W / W^{v}$ and $S I / S I^{d}$ mouse testes. Activation of KIT by KITL was demonstrated to directly induce SNAI2 expression in the bone marrow of wildtype animals (Perez-Losada et al. 2002). SNAI2 is also required for melanocyte development, effected by KIT activation through the mi/MITF transcription factor in melanoblasts (Sanchez-Martin et al. 2002). These studies reveal that SNAI2 is a molecular target in the KITL and KIT pathway activation. No direct evidence for a role of SNAI2 in the testis at the onset of spermatogenesis, when the KIT/KITL interaction is crucial, is currently available.

\section{Vascular endothelial growth factor}

Vascular endothelial growth factor (VEGF) is one of the most important mediators of tumour angiogenesis, and a relationship between VEGF and the KITL/KIT-signalling pathway has been established over the past decade. VEGF levels were suppressed following KIT inactivation by treatment with the tyrosine kinase inhibitor, imatinib mesylate/ST1571, in GIST (Bono et al. 2004, Jin et al. 2006), small lung cell cancer (Litz \& Krystal 2006) and neuroblastoma cell lines (Beppu et al. 2004). Use of the PI3K inhibitor, LY294002, has implicated KIT-mediated activation of $\mathrm{PI} 3 \mathrm{~K}$ in the regulation of VEGF mRNA, since the PI3K inhibitor led to reduced VEGF mRNA and protein levels (Litz \& Krystal 2006). In the testis, the relationship of VEGF to the KITL/KIT pathway has not yet been investigated.

\section{Cyclins}

The D-type cyclins, cyclin D1, D2 and D3 are required for progression of cells through the $\mathrm{G}_{1} / \mathrm{S}$ transition of the cell cycle (Feng et al. 2000). Expression studies indicate that cyclin D3 is present in spermatogonia of the immature mouse testis (Zhang et al. 1999), while cyclin $\mathrm{D} 2$ is required for spermatogonial differentiation in the adult (Beumer et al. 2000). KITL/KIT acts through the $\mathrm{PI} 3 \mathrm{~K}$ pathway to facilitate the up-regulation and nuclear accumulation of cyclin D3, thus inducing spermatogonial cells isolated from juvenile testis to proliferate (Feng et al. 2000, Dolci et al. 2001). The contribution of KITL/KIT to mediating cyclin D2 expression and subsequent spermatogonial differentiation in the adult testis is yet to be determined.

\section{Summary and prospects}

As knowledge of KIT-signalling biology expands, so does our potential to understand the intricate and interdependent manner in which testicular development and spermatogenesis occur. We know that KIT signalling drives many processes that are central to a wide variety of cellular activities, and each of these is, in some way, important to a particular stage of male germ cell maturation. It is therefore surprising that very little is known about the regulation of developmentalspecific KIT expression in the testis. Control of KIT regulation in the testis has been relatively underinvestigated in comparison with the number of studies in haematopoiesis and melanogenesis (summarized in Table 1). However, recent studies have identified several factors, including TGFB superfamily ligands, ILs and RA, which are each independently implicated in transcriptional and translational regulation of KIT; among these only RA and BMP4 have been shown to positively regulate KIT in germ cells from a juvenile testis. It is increasingly evident from the studies of haematopoiesis that TGFB1 and activin are likely to play roles in negative regulation of KIT. Identifying factors in the testicular niche, which enhance or suppress KIT levels, is paramount for understanding the complex molecular network that is active during the first wave of spermatogenesis and addressing how spermatogenesis is sustained through adulthood.

The transcription factors $\mathrm{SCL}, \mathrm{SP} 1$ and GATA1 are each implicated in non-testicular transcriptional regulation of KIT, while to date only ZBTB16 has been shown to be relevant for this in the testis. Transcriptional control of KIT in PGCs and spermatogonia is poorly understood, and understanding how this is achieved should reveal key components in the transcriptional network, which are deregulated in testicular germ cell tumours. Among the KIT downstream-signalling pathways, $\mathrm{PI} 3 \mathrm{~K}$ performs a broad repertoire of functions in the testis, affecting adhesion proliferation, survival 
and maturation of germ cells. Since KIT is present in both $\mathrm{CIS}$ and seminoma cells, it would be useful to identify the signalling pathways that are activated during testicular tumour progression. This review has intended to provide an up to date overview of the upstream regulators and downstream effectors of KIT signalling in testis and non-testicular tissues, with the objective of enabling future discoveries that will aid the treatment of male infertility and disease, and to provide new avenues for fertility control.

\section{Declaration of interest}

The authors declare that there is no conflict of interest that could be perceived as prejudicing the impartiality of the research/work reported.

\section{Funding}

This work was supported by grants from the NHMRC of Australia (\#545916, \#545917) and a Strategic Grant from the Monash University Faculty of Medicine Nursing and Health Sciences.

\section{References}

Agosti V, Corbacioglu S, Ehlers I, Waskow C, Sommer G, Berrozpe G, Kissel H, Tucker CM, Manova K, Moore MA et al. 2004 Critical role for kit-mediated Src kinase but not PI3-kinase signaling in pro T and pro B cell development. Journal of Experimental Medicine 199 867-878.

Albanesi C, Geremia R, Giorgio M, Dolci S, Sette C \& Rossi P 1996 A celland developmental stage-specific promoter drives the expression of a truncated c-kit protein during mouse spermatid elongation. Development 122 1291-1302.

Baleato RM, Aitken RJ \& Roman SD 2005 Vitamin A regulation of BMP4 expression in the male germ line. Developmental Biology 286 78-90.

Ballow D, Meistrich ML, Matzuk M \& Rajkovic A 2006 Sohlh1 is essential for spermatogonial differentiation. Developmental Biology 294 161-167.

Bellone G, Silvestri S, Artusio E, Tibaudi D, Turletti A, Geuna M, Giachino C, Valente G, Emanuelli G \& Rodeck U 1997 Growth stimulation of colorectal carcinoma cells via the c-kit receptor is inhibited by TGF-beta 1. Journal of Cellular Physiology 172 1-11.

Beppu K, Jaboine J, Merchant MS, Mackall CL \& Thiele CJ 2004 Effect of imatinib mesylate on neuroblastoma tumorigenesis and vascular endothelial growth factor expression. Journal of the National Cancer Institute 96 46-55.

Berrozpe G, Agosti V, Tucker C, Blanpain C, Manova K \& Besmer P 2006 A distant upstream locus control region is critical for expression of the Kit receptor gene in mast cells. Molecular and Cellular Biology 26 $5850-5860$.

Besmer P, Manova K, Duttlinger R, Huang EJ, Packer A, Gyssler C \& Bachvarova RF 1993 The kit-ligand (steel factor) and its receptor c-kit/W: pleiotropic roles in gametogenesis and melanogenesis. In Signals, Polarity and Adhesion in Development, pp 125-137. Eds P Ingham, A Brown \& A Martinez Arias. Cambridge, UK: The Company of Biologists.

Beumer TL, Roepers-Gajadien HL, Gademan IS, Kal HB \& de Rooij DG 2000 Involvement of the D-type cyclins in germ cell proliferation and differentiation in the mouse. Biology of Reproduction 63 1893-1898.

Blechman JM, Lev S, Givol D \& Yarden Y 1993 Structure-function analyses of the kit receptor for the steel factor. Stem Cells 11 12-21.

Blechman JM, Lev S, Barg J, Eisenstein M, Vaks B, Vogel Z, Givol D \& Yarden Y 1995 The fourth immunoglobulin domain of the stem cell factor receptor couples ligand binding to signal transduction. Cell 80 103-113.
Blume-Jensen P, Ronnstrand L, Gout I, Waterfield MD \& Heldin CH 1994 Modulation of Kit/stem cell factor receptor-induced signaling by protein kinase C. Journal of Biological Chemistry 269 21793-21802.

Blume-Jensen P, Janknecht R \& Hunter T 1998 The kit receptor promotes cell survival via activation of Pl3-kinase and subsequent Akt-mediated phosphorylation of Bad on Ser136. Current Biology 8 779-782.

Blume-Jensen P, Jiang G, Hyman R, Lee KF, O'Gorman S \& Hunter T 2000 $\mathrm{Kit} / \mathrm{stem}$ cell factor receptor-induced activation of phosphatidylinositol $3^{\prime}$-kinase is essential for male fertility. Nature Genetics 24 157-162.

Bono P, Krause A, von Mehren M, Heinrich MC, Blanke CD, Dimitrijevic S, Demetri GD \& Joensuu H 2004 Serum KIT and KIT ligand levels in patients with gastrointestinal stromal tumors treated with imatinib. Blood 103 2929-2935.

Burger PE, Lukey PT, Coetzee S \& Wilson EL 2002 Basic fibroblast growth factor modulates the expression of glycophorin A and c-kit and inhibits erythroid differentiation in K562 cells. Journal of Cellular Physiology 190 83-91.

Buzby JS, Knoppel EM \& Cairo MS 1994 Coordinate regulation of Steel factor, its receptor (Kit), and cytoadhesion molecule (ICAM-1 and ELAM-1) mRNA expression in human vascular endothelial cells of differing origins. Experimental Hematology 22 122-129.

Cairns LA, Moroni E, Levantini E, Giorgetti A, Klinger FG, Ronzoni S, Tatangelo L, Tiveron C, De Felici M, Dolci S et al. 2003 Kit regulatory elements required for expression in developing hematopoietic and germ cell lineages. Blood 102 3954-3962.

Caruana G, Cambareri AC \& Ashman LK 1999 Isoforms of c-KIT differ in activation of signalling pathways and transformation of NIH3T3 fibroblasts. Oncogene 18 5573-5581.

Chabot B, Stephenson DA, Chapman VM, Besmer P \& Bernstein A 1988 The proto-oncogene c-kit encoding a transmembrane tyrosine kinase receptor maps to the mouse W locus. Nature 335 88-89.

Chan AP \& Etkin LD 2001 Patterning and lineage specification in the amphibian embryo. Current Topics in Developmental Biology 51 1-67.

Chu TY \& Besmer P 1995 Characterization of the promoter of the protooncogene c-kit. Proceedings of the National Science Council, Republic of China. Part B, Life Sciences 19 8-18.

Costoya JA, Hobbs RM, Barna M, Cattoretti G, Manova K, Sukhwani M, Orwig KE, Wolgemuth DJ \& Pandolfi PP 2004 Essential role of Plzf in maintenance of spermatogonial stem cells. Nature Genetics $\mathbf{3 6}$ 653-659.

Dahlen DD, Lin NL, Liu YC \& Broudy VC 2001 Soluble Kit receptor blocks stem cell factor bioactivity in vitro. Leukemia Research 25 413-421.

De Felici M, Di Carlo A \& Pesce M 1996 Role of stem cell factor in somaticgerm cell interactions during prenatal oogenesis. Zygote 4 349-351.

Deberry C, Mou S \& Linnekin D 1997 Stat1 associates with c-kit and is activated in response to stem cell factor. Biochemical Journal 327 73-80.

Dolci S, Williams DE, Ernst MK, Resnick JL, Brannan CI, Lock LF, Lyman SD, Boswell HS \& Donovan PJ 1991 Requirement for mast cell growth factor for primordial germ cell survival in culture. Nature 352 809-811.

Dolci S, Pellegrini M, Di Agostino S, Geremia R \& Rossi P 2001 Signaling through extracellular signal-regulated kinase is required for spermatogonial proliferative response to stem cell factor. Journal of Biological Chemistry 276 40225-40233.

Dubois CM, Ruscetti FW, Stankova J \& Keller JR 1994 Transforming growth factor-beta regulates c-kit message stability and cell-surface protein expression in hematopoietic progenitors. Blood 83 3138-3145.

Duronio V, Scheid MP \& Ettinger S 1998 Downstream signalling events regulated by phosphatidylinositol 3-kinase activity. Cellular Signalling $10233-239$

Dym M, Jia MC, Dirami G, Price JM, Rabin SJ, Mocchetti I \& Ravindranath N 1995 Expression of c-kit receptor and its autophosphorylation in immature rat type A spermatogonia. Biology of Reproduction 52 8-19.

Farini D, La Sala G, Tedesco M \& De Felici M 2007 Chemoattractant action and molecular signaling pathways of Kit ligand on mouse primordial germ cells. Developmental Biology 306 572-583.

Felicetti F, Errico MC, Segnalini P, Mattia G \& Care A 2008 MicroRNA-221 and -222 pathway controls melanoma progression. Expert Review of Anticancer Therapy 8 1759-1765. 
Felli N, Fontana L, Pelosi E, Botta R, Bonci D, Facchiano F, Liuzzi F, Lulli V, Morsilli O, Santoro S et al. 2005 MicroRNAs 221 and 222 inhibit normal erythropoiesis and erythroleukemic cell growth via kit receptor downmodulation. PNAS 102 18081-18086.

Feng ZM, Wu AZ \& Chen CL 1998 Testicular GATA-1 factor up-regulates the promoter activity of rat inhibin alpha-subunit gene in MA-10 Leydig tumor cells. Molecular Endocrinology 12 378-390.

Feng LX, Ravindranath N \& Dym M 2000 Stem cell factor/c-kit up-regulates cyclin D3 and promotes cell cycle progression via the phosphoinositide 3-kinase/p70 S6 kinase pathway in spermatogonia. Journal of Biological Chemistry 275 25572-25576.

Filipponi D, Hobbs RM, Ottolenghi S, Rossi P, Jannini EA, Pandolfi PP \& Dolci S 2007 Repression of kit expression by Plzf in germ cells. Molecular and Cellular Biology 27 6770-6781.

Flanagan JG, Chan DC \& Leder P 1991 Transmembrane form of the kit ligand growth factor is determined by alternative splicing and is missing in the Sld mutant. Cell 64 1025-1035.

Godin I, Deed R, Cooke J, Zsebo K, Dexter M \& Wylie CC 1991 Effects of the steel gene product on mouse primordial germ cells in culture. Nature $352807-809$.

Gommerman JL, Sittaro D, Klebasz NZ, Williams DA \& Berger SA 2000 Differential stimulation of c-Kit mutants by membrane-bound and soluble steel factor correlates with leukemic potential. Blood $\mathbf{9 6}$ 3734-3742.

Gotoh A, Takahira H, Mantel C, Litz-Jackson S, Boswell HS \& Broxmeyer HE 1996 Steel factor induces serine phosphorylation of Stat 3 in human growth factor-dependent myeloid cell lines. Blood $\mathbf{8 8}$ 138-145.

Gu Y, Runyan C, Shoemaker A, Surani A \& Wylie C 2009 Steel factor controls primordial germ cell survival and motility from the time of their specification in the allantois, and provides a continuous niche throughout their migration. Development 136 1295-1303.

Guerif F, Cadoret V, Rahal-Perola V, Lansac J, Bernex F, Jacques Panthier J, Hochereau-de Reviers MT \& Royere D 2002 Apoptosis, onset and maintenance of spermatogenesis: evidence for the involvement of Kit in Kit-haplodeficient mice. Biology of Reproduction 67 70-79.

Hassan HT \& Zander A 1996 Stem cell factor as a survival and growth factor in human normal and malignant hematopoiesis. Acta Haematologica 95 257-262.

Hasthorpe S, Barbic S, Farmer PJ \& Hutson JM 1999 Neonatal mouse gonocyte proliferation assayed by an in vitro clonogenic method. Journal of Reproduction and Fertility 116 335-344.

Hayashi S, Kunisada T, Ogawa M, Yamaguchi K \& Nishikawa S 1991 Exon skipping by mutation of an authentic splice site of c-kit gene in W/W mouse. Nucleic Acids Research 19 1267-1271.

He L \& Hannon GJ 2004 MicroRNAs: small RNAs with a big role in gene regulation. Nature Reviews. Genetics 5 522-531.

Heinrich MC, Dooley DC \& Keeble WW 1995 Transforming growth factor beta 1 inhibits expression of the gene products for steel factor and its receptor (c-kit). Blood 85 1769-1780.

Hino M, Nishizawa Y, Tatsumi N, Tojo A \& Morii H 1995 Downmodulation of c-kit mRNA and protein expression by erythroid differentiation factor/activin A. FEBS Letters 374 69-71.

Hogg A, Schirm S, Nakagoshi H, Bartley P, Ishii S, Bishop JM \& Gonda TJ 1997 Inactivation of a c-Myb/estrogen receptor fusion protein in transformed primary cells leads to granulocyte/macrophage differentiation and down regulation of c-kit but not c-myc or cdc2. Oncogene 15 2885-2898.

Hong SM, Frierson HF Jr \& Moskaluk CA 2005 AP-2gamma protein expression in intratubular germ cell neoplasia of testis. American Journal of Clinical Pathology 124 873-877.

Hu J, Chen YX, Wang D, Qi X, Li TG, Hao J, Mishina Y, Garbers DL \& Zhao GQ 2004 Developmental expression and function of Bmp4 in spermatogenesis and in maintaining epididymal integrity. Developmental Biology 276 158-171.

Hu JH, Navas P, Cao H, Stamatoyannopoulos G \& Song CZ 2007 Systematic RNAi studies on the role of Sp/KLF factors in globin gene expression and erythroid differentiation. Journal of Molecular Biology 366 1064-1073.

Huang EJ, Nocka KH, Buck J \& Besmer P 1992 Differential expression and processing of two cell associated forms of the kit-ligand: KL-1 and KL-2. Molecular Biology of the Cell 3 349-362.
Huang S, Jean D, Luca M, Tainsky MA \& Bar-Eli M 1998 Loss of AP-2 results in downregulation of C-KIT and enhancement of melanoma tumorigenicity and metastasis. EMBO Journal 17 4358-4369.

Ishiga K, Kawatani T, Tajima F, Omura H, Nanba E \& Kawasaki H 2000 Serum-soluble c-kit levels during mobilization of peripheral blood stem cells correlate with stem cell yield. International Journal of Hematology 72 186-193.

Itman C, Mendis S, Barakat B \& Loveland KL 2006 All in the family: TGFbeta family action in testis development. Reproduction 132 233-246.

Ito $E$, Toki T, Ishihara $H$, Ohtani H, Gu L, Yokoyama M, Engel JD \& Yamamoto M 1993 Erythroid transcription factor GATA-1 is abundantly transcribed in mouse testis. Nature 362 466-468.

Ito $M$, Kawa $Y$, Watabe $H$, Ono $H$, Ooka $S$, Nakamura $M$, Soma $Y$ \& Mizoguchi M 2004 Establishment by an original single-cell cloning method and characterization of an immortal mouse melanoblast cell line (NCCmelb4). Pigment Cell Research 17 643-650.

Jacobsen FW, Dubois CM, Rusten LS, Veiby OP \& Jacobsen SE 1995 Inhibition of stem cell factor-induced proliferation of primitive murine hematopoietic progenitor cells signaled through the 75-kilodalton tumor necrosis factor receptor. Regulation of c-kit and p53 expression. Journal of Immunology 154 3732-3741.

Jin T, Nakatani H, Taguchi T, Nakano T, Okabayashi T, Sugimoto T, Kobayashi M \& Araki K 2006 STI571 (Glivec) suppresses the expression of vascular endothelial growth factor in the gastrointestinal stromal tumor cell line, GIST-T1. World Journal of Gastroenterology 12 703-708.

Kanetsky PA, Mitra N, Vardhanabhuti S, Li M, Vaughn DJ, Letrero R, Ciosek SL, Doody DR, Smith LM, Weaver J et al. 2009 Common variation in KITLG and at $5 q 31.3$ predisposes to testicular germ cell cancer. Nature Genetics 41 811-815.

Karafiat V, Dvorakova M, Pajer P, Cermak V \& Dvorak M 2007 Melanocyte fate in neural crest is triggered by Myb proteins through activation of c-kit. Cellular and Molecular Life Sciences 64 2975-2984.

Kawakami K, Sato S, Ozaki H \& Ikeda K 2000 Six family genes - structure and function as transcription factors and their roles in development. BioEssays 22 616-626.

Kawakami T, Soma Y, Kawa Y, Ito M, Yamasaki E, Watabe H, Hosaka E, Yajima K, Ohsumi K \& Mizoguchi M 2002 Transforming growth factor beta1 regulates melanocyte proliferation and differentiation in mouse neural crest cells via stem cell factor/KIT signaling. Journal of Investigative Dermatology 118 471-478.

Kawakami T, Kimura S, Kawa Y, Kato M, Mizoguchi M \& Soma Y 2008 BMP-4 upregulates Kit expression in mouse melanoblasts prior to the Kitdependent cycle of melanogenesis. Journal of Investigative Dermatology 128 1220-1226.

Khoury E, Andre C, Pontvert-Delucq S, Drenou B, Baillou C, Guigon M, Najman A \& Lemoine FM 1994 Tumor necrosis factor alpha (TNF alpha) downregulates c-kit proto-oncogene product expression in normal and acute myeloid leukemia CD34+ cells via p55 TNF alpha receptors. Blood 84 2506-2514.

Kissel H, Timokhina I, Hardy MP, Rothschild G, Tajima Y, Soares V, Angeles M, Whitlow SR, Manova K \& Besmer P 2000 Point mutation in kit receptor tyrosine kinase reveals essential roles for kit signaling in spermatogenesis and oogenesis without affecting other kit responses. EMBO Journal 19 1312-1326.

Kitamura Y \& Hirotab S 2004 Kit as a human oncogenic tyrosine kinase. Cellular and Molecular Life Sciences 61 2924-2931.

Konig A, Corbacioglu S, Ballmaier M \& Welte K 1997 Downregulation of c-kit expression in human endothelial cells by inflammatory stimuli. Blood 90 148-155.

Krosl G, He G, Lefrancois M, Charron F, Romeo PH, Jolicoeur P, Kirsch IR, Nemer M \& Hoang T 1998 Transcription factor SCL is required for c-kit expression and c-Kit function in hemopoietic cells. Journal of Experimental Medicine 188 439-450.

Lahm H, Amstad P, Yilmaz A, Borbenyi Z, Wyniger J, Fischer JR, Suardet L, Givel JC \& Odartchenko N 1995 Interleukin 4 down-regulates expression of c-kit and autocrine stem cell factor in human colorectal carcinoma cells. Cell Growth and Differentiation 6 1111-1118.

Lecuyer E, Herblot S, Saint-Denis M, Martin R, Begley CG, Porcher C, Orkin SH \& Hoang T 2002 The SCL complex regulates c-kit expression in hematopoietic cells through functional interaction with Sp1. Blood $1002430-2440$. 
Lev S, Yarden Y \& Givol D 1992 Dimerization and activation of the kit receptor by monovalent and bivalent binding of the stem cell factor. Journal of Biological Chemistry 267 15970-15977.

Linnekin D 1999 Early signaling pathways activated by c-Kit in hematopoietic cells. International Journal of Biochemistry and Cell Biology 31 1053-1074.

Linnekin D, Weiler SR, Mou S, DeBerry CS, Keller JR, Ruscetti FW, Ferris DK \& Longo DL 1996 JAK2 is constitutively associated with c-Kit and is phosphorylated in response to stem cell factor. Acta Haematologica 95 224-228.

Linnekin D, DeBerry CS \& Mou S 1997 Lyn associates with the juxtamembrane region of c-Kit and is activated by stem cell factor in hematopoietic cell lines and normal progenitor cells. Journal of Biological Chemistry 272 27450-27455.

Litz J \& Krystal GW 2006 Imatinib inhibits c-Kit-induced hypoxia-inducible factor-1alpha activity and vascular endothelial growth factor expression in small cell lung cancer cells. Molecular Cancer Therapeutics 5 $1415-1422$.

Looijenga LH, Gillis AJ, Stoop H, Hersmus R \& Oosterhuis JW 2007 Relevance of microRNAs in normal and malignant development, including human testicular germ cell tumours. International Journal of Andrology 30 304-314 (discussion 314-305).

Loveland KL \& Schlatt S 1997 Stem cell factor and c-kit in the mammalian testis: lessons originating from Mother Nature's gene knockouts. Journal of Endocrinology 153 337-344.

Loveland KL, Dias V, Meachem S \& Rajpert-De Meyts E 2007 The transforming growth factor-beta superfamily in early spermatogenesis: potential relevance to testicular dysgenesis. International Journal of Andrology 30 377-384.

McCarrey JR 1993 Development of the germ cell. In Cell and Molecular Biology of the Testis, pp 58-89. Eds C Desjardins \& LL Ewing. New York: Oxford University Press.

Manova K \& Bachvarova RF 1991 Expression of c-kit encoded at the W locus of mice in developing embryonic germ cells and presumptive melanoblasts. Developmental Biology 146 312-324.

Martin FH, Suggs SV, Langley KE, Lu HS, Ting J, Okino KH, Morris CF, McNiece IK, Jacobsen FW, Mendiaz EA et al. 1990 Primary structure and functional expression of rat and human stem cell factor DNAs. Cell 63 203-211.

Matsui Y, Zsebo KM \& Hogan BL 1990 Embryonic expression of a haematopoietic growth factor encoded by the SI locus and the ligand for c-kit. Nature 347 667-669.

Mirmonsef P, Shelburne CP, Fitzhugh Yeatman C II, Chong HJ \& Ryan JJ 1999 Inhibition of Kit expression by IL-4 and IL-10 in murine mast cells: role of STAT6 and phosphatidylinositol 3'-kinase. Journal of Immunology $1632530-2539$.

Miyazawa K, Williams DA, Gotoh A, Nishimaki J, Broxmeyer HE \& Toyama K 1995 Membrane-bound steel factor induces more persistent tyrosine kinase activation and longer life span of c-kit gene-encoded protein than its soluble form. Blood 85 641-649.

Montero JC, Lopez-Perez R, San Miguel JF \& Pandiella A 2008 Expression of c-Kit isoforms in multiple myeloma: differences in signaling and drug sensitivity. Haematologica 93 851-859.

Munugalavadla V, Dore LC, Tan BL, Hong L, Vishnu M, Weiss MJ \& Kapur R 2005 Repression of c-kit and its downstream substrates by GATA-1 inhibits cell proliferation during erythroid maturation. Molecular and Cellular Biology 25 6747-6759.

Nakamura Y, Tajima F, Ishiga K, Yamazaki H, Oshimura M, Shiota G \& Murawaki Y 2004 Soluble c-kit receptor mobilizes hematopoietic stem cells to peripheral blood in mice. Experimental Hematology 32 390-396.

Neta R, Oppenheim JJ, Wang JM, Snapper CM, Moorman MA \& Dubois CM 1994 Synergy of IL-1 and stem cell factor in radioprotection of mice is associated with IL-1 up-regulation of mRNA and protein expression for c-kit on bone marrow cells. Journal of Immunology 153 1536-1543.

Nieto MA, Sargent MG, Wilkinson DG \& Cooke J 1994 Control of cell behavior during vertebrate development by Slug, a zinc finger gene. Science 264 835-839.

Norozian F, Kashyap M, Ramirez CD, Patel N, Kepley CL, Barnstein BO \& Ryan JJ 2006 TGFbeta1 induces mast cell apoptosis. Experimental Hematology 34 579-587.
Ohta H, Yomogida K, Dohmae K \& Nishimune Y 2000 Regulation of proliferation and differentiation in spermatogonial stem cells: the role of c-kit and its ligand SCF. Development 127 2125-2131.

Ohta H, Tohda A \& Nishimune Y 2003 Proliferation and differentiation of spermatogonial stem cells in the w/wv mutant mouse testis. Biology of Reproduction 69 1815-1821.

Okada S \& Suda T 1992 Function, molecular structure and gene expression of stem cell factor (SCF). Nippon Rinsho. Japanese Journal of Clinical Medicine 50 1872-1878.

Onodera K, Yomogida K, Suwabe N, Takahashi S, Muraosa Y, Hayashi N, Ito E, Gu L, Rassoulzadegan M, Engel JD et al. 1997 Conserved structure, regulatory elements, and transcriptional regulation from the GATA-1 gene testis promoter. Journal of Biochemistry 121 251-263.

Orr-Urtreger A, Avivi A, Zimmer Y, Givol D, Yarden Y \& Lonai P 1990 Developmental expression of c-kit, a proto-oncogene encoded by the $\mathrm{W}$ locus. Development 109 911-923.

Orth JM, Qiu J, Jester WF Jr \& Pilder S 1997 Expression of the c-kit gene is critical for migration of neonatal rat gonocytes in vitro. Biology of Reproduction 57 676-683.

Packer Al, Besmer P \& Bachvarova RF 1995 Kit ligand mediates survival of type A spermatogonia and dividing spermatocytes in postnatal mouse testes. Molecular Reproduction and Development 42 303-310.

Park GH, Plummer HK III \& Krystal GW 1998 Selective Sp1 binding is critical for maximal activity of the human c-kit promoter. Blood 92 4138-4149.

Pauls K, Jager R, Weber S, Wardelmann E, Koch A, Buttner R \& Schorle H 2005 Transcription factor AP-2gamma, a novel marker of gonocytes and seminomatous germ cell tumors. International Journal of Cancer $\mathbf{1 1 5}$ 470-477.

Pellegrini M, Grimaldi P, Rossi P, Geremia R \& Dolci S 2003 Developmental expression of BMP4/ALK3/SMAD5 signaling pathway in the mouse testis: a potential role of BMP4 in spermatogonia differentiation. Journal of Cell Science 116 3363-3372.

Pellegrini M, Filipponi D, Gori M, Barrios F, Lolicato F, Grimaldi P, Rossi P, Jannini EA, Geremia R \& Dolci S 2008 ATRA and KL promote differentiation toward the meiotic program of male germ cells. Cell Cycle 7 3878-3888.

Perez-Losada J, Sanchez-Martin M, Rodriguez-Garcia A, Sanchez ML, Orfao A, Flores T \& Sanchez-Garcia I 2002 Zinc-finger transcription factor Slug contributes to the function of the stem cell factor c-kit signaling pathway. Blood 100 1274-1286.

Piao X, Paulson R, van der Geer P, Pawson T \& Bernstein A 1996 Oncogenic mutation in the Kit receptor tyrosine kinase alters substrate specificity and induces degradation of the protein tyrosine phosphatase SHP-1. PNAS 93 14665-14669.

Prabhu SM, Meistrich ML, McLaughlin EA, Roman SD, Warne S, Mendis S, Itman C \& Loveland KL 2006 Expression of c-Kit receptor mRNA and protein in the developing, adult and irradiated rodent testis. Reproduction 131 489-499.

Quaranta MT, Spinello I, Testa U, Mariani G, Diverio D, Foa R, Peschle C \& Labbaye C 2006 PLZF-mediated control on VLA-4 expression in normal and leukemic myeloid cells. Oncogene 25 399-408.

Rajpert-De Meyts E \& Skakkebaek NE 1994 Expression of the c-kit protein product in carcinoma-in-situ and invasive testicular germ cell tumours. International Journal of Andrology 17 85-92.

Rapley EA, Turnbull C, Al Olama AA, Dermitzakis ET, Linger R, Huddart RA, Renwick A, Hughes D, Hines S, Seal S et al. 2009 A genome-wide association study of testicular germ cell tumor. Nature Genetics 41 807-810.

Ratajczak MZ, Perrotti D, Melotti P, Powzaniuk M, Calabretta B, Onodera K, Kregenow DA, Machalinski B \& Gewirtz AM 1998 Myb and ets proteins are candidate regulators of c-kit expression in human hematopoietic cells. Blood 91 1934-1946.

Reber L, Da Silva CA \& Frossard N 2006 Stem cell factor and its receptor c-Kit as targets for inflammatory diseases. European Journal of Pharmacology 533 327-340.

Reith AD, Ellis C, Lyman SD, Anderson DM, Williams DE, Bernstein A \& Pawson T 1991 Signal transduction by normal isoforms and W mutant variants of the Kit receptor tyrosine kinase. EMBO Journal 10 2451-2459.

de Rooij DG, Okabe M \& Nishimune Y 1999 Arrest of spermatogonial differentiation in jsd/jsd, $\mathrm{Sl} 17 \mathrm{H} / \mathrm{S} / 17 \mathrm{H}$, and cryptorchid mice. Biology of Reproduction 61 842-847. 
Roskoski R Jr 2005 Signaling by Kit protein-tyrosine kinase - the stem cell factor receptor. Biochemical and Biophysical Research Communications 337 1-13.

Rossi P, Albanesi C, Grimaldi P \& Geremia R 1991 Expression of the mRNA for the ligand of c-kit in mouse Sertoli cells. Biochemical and Biophysical Research Communications 176 910-914.

Rossi P, Lolicato F, Grimaldi P, Dolci S, Di Sauro A, Filipponi D \& Geremia R 2008 Transcriptome analysis of differentiating spermatogonia stimulated with kit ligand. Gene Expression Patterns 8 58-70.

Rothschild G, Sottas CM, Kissel H, Agosti V, Manova K, Hardy MP \& Besmer P 2003 A role for kit receptor signaling in Leydig cell steroidogenesis. Biology of Reproduction 69 925-932.

Runyan C, Schaible K, Molyneaux K, Wang Z, Levin L \& Wylie C 2006 Steel factor controls midline cell death of primordial germ cells and is essential for their normal proliferation and migration. Development 133 4861-4869.

Ryan JJ, Huang H, McReynolds LJ, Shelburne C, Hu-Li J, Huff TF \& Paul WE 1997 Stem cell factor activates STAT-5 DNA binding in IL-3-derived bone marrow mast cells. Experimental Hematology 25 357-362.

Samayawardhena LA, Kapur R \& Craig AW 2007 Involvement of Fyn kinase in Kit and integrin-mediated Rac activation, cytoskeletal reorganization and chemotaxis of mast cells. Blood 109 3679-3686.

Sanchez-Martin M, Rodriguez-Garcia A, Perez-Losada J, Sagrera A, Read AP \& Sanchez-Garcia I 2002 SLUG (SNAI2) deletions in patients with Waardenburg disease. Human Molecular Genetics 11 3231-3236.

Sansilvestri P, Cardoso AA, Batard P, Panterne B, Hatzfeld A, Lim B, Levesque JP, Monier MN \& Hatzfeld J 1995 Early CD34high cells can be separated into KIThigh cells in which transforming growth factor-beta (TGF-beta) downmodulates c-kit and KITlow cells in which anti-TGFbeta upmodulates c-kit. Blood 86 1729-1735.

Sarkar PS, Paul S, Han J \& Reddy S 2004 Six5 is required for spermatogenic cell survival and spermiogenesis. Human Molecular Genetics 13 1421-1431.

Sattler M \& Salgia R 2004 Targeting c-Kit mutations: basic science to novel therapies. Leukemia Research 28 S11-S20.

Schmierer B \& Hill CS 2007 TGF $\beta-S M A D$ signal transduction: molecular specificity and functional flexibility. Nature Reviews. Molecular Cell Biology 8 970-982.

Schnabel D, Ramirez L, Gertsenstein M, Nagy A \& Lomeli H 2005 Ectopic expression of KitD814Y in spermatids of transgenic mice, interferes with sperm morphogenesis. Developmental Dynamics 233 29-40.

Schrans-Stassen BH, van de Kant HJ, de Rooij DG \& van Pelt AM 1999 Differential expression of c-kit in mouse undifferentiated and differentiating type A spermatogonia. Endocrinology 140 5894-5900.

Serve H, Hsu YC \& Besmer P 1994 Tyrosine residue 719 of the c-kit receptor is essential for binding of the P85 subunit of phosphatidylinositol (PI) 3-kinase and for c-kit-associated PI 3-kinase activity in COS-1 cells. Journal of Biological Chemistry 269 6026-6030.

Sette C, Bevilacqua A, Bianchini A, Mangia F, Geremia R \& Rossi P 1997 Parthenogenetic activation of mouse eggs by microinjection of a truncated c-kit tyrosine kinase present in spermatozoa. Development $1242267-2274$.

Sette C, Bevilacqua A, Geremia R \& Rossi P 1998 Involvement of phospholipase $C_{\gamma} 1$ in mouse egg activation induced by a truncated form of the C-kit tyrosine kinase present in spermatozoa. Journal of Cell Biology 142 1063-1074.

Sette C, Paronetto MP, Barchi M, Bevilacqua A, Geremia R \& Rossi P 2002 Tr-kit-induced resumption of the cell cycle in mouse eggs requires activation of a Src-like kinase. EMBO Journal 21 5386-5395.

Shepherd PR, Withers DJ \& Siddle K 1998 Phosphoinositide 3-kinase: the key switch mechanism in insulin signalling. Biochemical Journal 333 471-490.

Shinohara T, Avarbock MR \& Brinster RL 1999 $\beta 1$ - and $\alpha 6$-Integrin are surface markers on mouse spermatogonial stem cells. PNAS $\mathbf{9 6}$ 5504-5509.

Shinohara T, Orwig KE, Avarbock MR \& Brinster RL 2000 Spermatogonial stem cell enrichment by multiparameter selection of mouse testis cells. PNAS 97 8346-8351.

Shivakrupa R \& Linnekin D 2005 Lyn contributes to regulation of multiple Kit-dependent signaling pathways in murine bone marrow mast cells. Cellular Signalling 17 103-109.
Sillaber C, Strobl H, Bevec D, Ashman LK, Butterfield JH, Lechner K, Maurer D, Bettelheim P \& Valent P 1991 IL-4 regulates c-kit protooncogene product expression in human mast and myeloid progenitor cells. Journal of Immunology 147 4224-4228.

Sorrentino V, Giorgi M, Geremia R, Besmer P \& Rossi P 1991 Expression of the c-kit proto-oncogene in the murine male germ cells. Oncogene $\mathbf{6}$ 149-151.

Spinello I, Quaranta MT, Pasquini L, Pelosi E, Petrucci E, Pagliuca A, Castelli G, Mariani G, Diverio D, Foa R et al. 2009 PLZF-mediated control on c-kit expression in CD34 $(+)$ cells and early erythropoiesis. Oncogene 28 2276-2288.

Tajima Y, Sakamaki K, Watanabe D, Koshimizu U, Matsuzawa T \& Nishimune Y 1991a Steel-Dickie (SId) mutation affects both maintenance and differentiation of testicular germ cells in mice. Journal of Reproduction and Fertility 91 441-449.

Tajima Y, Onoue H, Kitamura Y \& Nishimune Y 1991b Biologically active kit ligand growth factor is produced by mouse Sertoli cells and is defective in SId mutant mice. Development 113 1031-1035.

Tajima Y, Sawada K, Morimoto T \& Nishimune Y 1994 Switching of mouse spermatogonial proliferation from the c-kit receptor-independent type to the receptor-dependent type during differentiation. Journal of Reproduction and Fertility 102 117-122.

Tajima F, Kawatani T, Ishiga K, Nanba E \& Kawasaki H 1998 Serum soluble $\mathrm{c}$-kit receptor and expression of c-kit protein and $\mathrm{mRNA}$ in acute myeloid leukemia. European Journal of Haematology 60 289-296.

Tang B, Mano H, Yi T \& Ihle JN 1994 Tec kinase associates with c-kit and is tyrosine phosphorylated and activated following stem cell factor binding. Molecular and Cellular Biology 14 8432-8437.

Thommes K, Lennartsson J, Carlberg M \& Ronnstrand L 1999 Identification of Tyr-703 and Tyr-936 as the primary association sites for Grb2 and Grb7 in the c-Kit/stem cell factor receptor. Biochemical Journal 341 211-216.

Timokhina I, Kissel H, Stella G \& Besmer P 1998 Kit signaling through PI 3-kinase and Src kinase pathways: an essential role for Rac1 and JNK activation in mast cell proliferation. EMBO Journal 17 6250-6262.

Toksoz D, Zsebo KM, Smith KA, Hu S, Brankow D, Suggs SV, Martin FH \& Williams DA 1992 Support of human hematopoiesis in long-term bone marrow cultures by murine stromal cells selectively expressing the membrane-bound and secreted forms of the human homolog of the steel gene product, stem cell factor. PNAS 89 7350-7354.

Tomeczkowski J, Frick D, Schwinzer B, Wittner N, Ludwig WD, Reiter A, Welte K \& Sykora KW 1998 Expression and regulation of c-kit receptor and response to stem cell factor in childhood malignant T-lymphoblastic cells. Leukemia 12 1221-1229.

Toyoda S, Miyazaki T, Miyazaki S, Yoshimura T, Yamamoto M, Tashiro F, Yamato E \& Miyazaki J 2009 Sohlh2 affects differentiation of KIT positive oocytes and spermatogonia. Developmental Biology 325 238-248.

Tulina N \& Matunis E 2001 Control of stem cell self-renewal in Drosophila spermatogenesis by JAK-STAT signaling. Science 294 2546-2549.

Ueda S, Mizuki M, Ikeda H, Tsujimura T, Matsumura I, Nakano K, Daino H, Honda Zi Z, Sonoyama J, Shibayama H et al. 2002 Critical roles of C-Kit tyrosine residues 567 and 719 in stem cell factor-induced chemotaxis: contribution of src family kinase and PI3-kinase on calcium mobilization and cell migration. Blood $993342-3349$.

Vandenbark GR, Chen Y, Friday E, Pavlik K, Anthony B, deCastro C \& Kaufman RE 1996 Complex regulation of human c-kit transcription by promoter repressors, activators, and specific myb elements. Cell Growth and Differentiation 7 1383-1392.

Vegiopoulos A, Garcia P, Emambokus N \& Frampton J 2006 Coordination of erythropoiesis by the transcription factor C-Myb. Blood $\mathbf{1 0 7}$ 4703-4710.

Vincent S, Segretain D, Nishikawa S, Nishikawa SI, Sage J, Cuzin F \& Rassoulzadegan M 1998 Stage-specific expression of the Kit receptor and its ligand $(\mathrm{KL})$ during male gametogenesis in the mouse: a Kit-KL interaction critical for meiosis. Development 125 4585-4593.

Voytyuk O, Lennartsson J, Mogi A, Caruana G, Courtneidge S, Ashman LK \& Ronnstrand L 2003 Src family kinases are involved in the differential signaling from two splice forms of c-Kit. Journal of Biological Chemistry 278 9159-9166. 
Wang Y \& Culty M 2007 Identification and distribution of a novel plateletderived growth factor receptor beta variant: effect of retinoic acid and involvement in cell differentiation. Endocrinology 148 2233-2250.

Welker P, Grabbe J, Zuberbier T, Grutzkau A \& Henz BM 2001 GM-CSF downmodulates c-kit, Fc(epsilon)RI(alpha) and GM-CSF receptor expression as well as histamine and tryptase levels in cultured human mast cells. Archives for Dermatological Research. Archiv für Dermatologische Forschung 293 249-258.

Wypych J, Bennett LG, Schwartz MG, Clogston CL, Lu HS, Broudy VC, Bartley TD, Parker VP \& Langley KE 1995 Soluble kit receptor in human serum. Blood 85 66-73.

Yamamoto K, Tojo A, Aoki N \& Shibuya M 1993 Characterization of the promoter region of the human c-kit proto-oncogene. Japanese Journal of Cancer Research 84 1136-1144.

Yan W, Suominen J \& Toppari J 2000a Stem cell factor protects germ cells from apoptosis in vitro. Journal of Cell Science 113 161-168.

Yan W, Kero J, Huhtaniemi I \& Toppari J 2000 b Stem cell factor functions as a survival factor for mature Leydig cells and a growth factor for precursor Leydig cells after ethylene dimethane sulfonate treatment: implication of a role of the stem cell factor/c-Kit system in Leydig cell development. Developmental Biology 227 169-182.

Yarden Y, Kuang WJ, Yang-Feng T, Coussens L, Munemitsu S, Dull TJ, Chen E, Schlessinger J, Francke U \& Ullrich A 1987 Human protooncogene c-kit: a new cell surface receptor tyrosine kinase for an unidentified ligand. EMBO Journal 6 3341-3351.

Yasuda H, Galli SJ \& Geissler EN 1993 Cloning and functional analysis of the mouse c-kit promoter. Biochemical and Biophysical Research Communications 191 893-901.

Yomogida K, Ohtani H, Harigae H, Ito E, Nishimune Y, Engel JD \& Yamamoto M 1994 Developmental stage- and spermatogenic cyclespecific expression of transcription factor GATA-1 in mouse Sertoli cells. Development 120 1759-1766.
Yoshinaga K, Nishikawa S, Ogawa M, Hayashi S, Kunisada T, Fujimoto T \& Nishikawa S 1991 Role of c-kit in mouse spermatogenesis: identification of spermatogonia as a specific site of c-kit expression and function. Development 113 689-699.

Zhang Q, Wang X \& Wolgemuth DJ 1999 Developmentally regulated expression of cyclin D3 and its potential in vivo interacting proteins during murine gametogenesis. Endocrinology 140 2790-2800.

Zhang Z, Zhang R, Joachimiak A, Schlessinger J \& Kong XP 2000 Crystal structure of human stem cell factor: implication for stem cell factor receptor dimerization and activation. PNAS 97 7732-7737.

Zhou Q, Li Y, Nie R, Friel P, Mitchell D, Evanoff RM, Pouchnik D, Banasik B, McCarrey JR, Small C et al. 2007 Expression of stimulated by retinoic acid gene 8 (Stra8) and maturation of murine gonocytes and spermatogonia induced by retinoic acid in vitro. Biology of Reproduction 78 537-545.

Zsebo KM, Williams DA, Geissler EN, Broudy VC, Martin FH, Atkins HL, Hsu RY, Birkett NC, Okino KH, Murdock DC et al. 1990a Stem cell factor is encoded at the SI locus of the mouse and is the ligand for the c-kit tyrosine kinase receptor. Cell 63 213-224.

Zsebo KM, Wypych J, McNiece IK, Lu HS, Smith KA, Karkare SB, Sachdev RK, Yuschenkoff VN, Birkett NC, Williams LR et al. 1990b Identification, purification, and biological characterization of hematopoietic stem cell factor from buffalo rat liver - conditioned medium. Cell 63 195-201.

Received 29 December 2008

First decision 9 February 2009

Revised manuscript received 10 June 2009

Accepted 29 June 2009 